International Journal of Child, Youth and Family Studies (2020) 11(4.2): 37-56

DOI: $10.18357 /$ ijcyfs 114.2202019987

\title{
ELEMENTS IN SCHOOL PRINCIPALSHIP: THE CHANGING ROLE OF PEDAGOGY AND THE GROWING RECOGNITION OF EMOTIONAL LITERACY
}

\author{
Alexander Schneider and Einat Yitzhak-Monsonego
}

\begin{abstract}
This paper examines the changing role of pedagogy and the growing recognition of emotional literacy as an element in school principalship, as perceived by school principals. A model of the "principal's toolkit" based on three "pillars" of leadership, management, and pedagogy was used, but with the addition of a fourth pillar, emotional literacy. Here we report on a survey of 63 principals and educational executives that was designed to examine principals' views regarding which tools are required for school principalship, the way they prioritize those tools, and the weight accorded to each. The survey, which took place from September 2009 to July 2010, was conducted through a questionnaire and interviews. Quantitative processing of the questionnaire results was performed, as was content analysis of the open questions and the interviews. The findings clearly define and rate the components of the essential toolkit for principalship as perceived by the principals. Leadership and emotional literacy were rated highest and pedagogy and management lower, which is at odds with the prevailing attempt by the Israeli Ministry of Education to establish pedagogical leadership as the central element in principalship. This paper will explore and explain the phenomenon of change in principalship elements that entails the changing role of pedagogy and the increasing importance of emotional literacy as an element in school principalship.
\end{abstract}

Keywords: leadership, management, pedagogy, school principalship, emotional literacy, principal training and development

Alexander Schneider $\mathrm{PhD}$ (corresponding author) is an Educator and Educational Researcher at the Beit Berl Research and Evaluation Unit, Beit Berl Academic College, Post Beit Berl 4490500, Israel. Email: drschneidera@gmail.com

Einat Yitzhak-Monsonego $\mathrm{PhD}$ is a researcher at the Beit Berl Research and Evaluation Unit, Beit Berl Academic College, Post Beit Berl 4490500, Israel. Email: einat@ beitberl.ac.il 
International Journal of Child, Youth and Family Studies (2020) 11(4.2): 37-56

The first decades of the 21st century have witnessed a change in educational approaches in the Western world, a change that has led to a substantial and continuous growth in the responsibilities that school principals are expected to assume, leading to substantial changes in the nature of the work. In addition to the traditional responsibilities of the role, engagement with the local community and with society in general has come to be among the ordinary duties of principalship (Bisschoff, 2014).

Davies (1997) pointed out the implications of these changes for the world of education:

In this world the globalization of economic systems, technological advance and the increased expectations that society has of its education system have replaced past certainties with new and uncertain frameworks. Dynamic changes have become the order of the day. How do leaders and managers meet this challenge and develop approaches in order to operate successfully in this new environment? (p. 11)

Traditionally, the "school principalship toolkit" was based upon three pillars: leadership, administration, and pedagogy (Campbell, 1999). However, changes in the role of school principal seem to have reduced the weight placed on pedagogy as a main element in school principalship, leading to the recognition and implementation of the newly defined element of emotional literacy as a fourth pillar (Schneider, 2004; Schneider \& Burton, 2008).

The Hebrew word for school principal is menahel, literally, "manager", although they have generally been thought of as "head teachers" or "senior teachers. Under past practice, the principal was selected from among the teachers to serve as a central figure whose main role was to focus on providing pedagogical, methodological, and didactic guidance (in which he or she was expected to be expert) to the teaching staff. Principals' leadership came primarily from their position within the teaching circle, based on their pedagogical seniority. This fact formed and shaped, to a great extent, the range of responsibilities principals carried in the school system. The Ministry of Education tried to help with school organization tasks by freeing the principals from administrative and personnel-related responsibilities, allowing them to devote most of their time and energy to pedagogical issues (Schneider \& Barkol, 2007). This approach has changed in the last decade with the tendency to move toward self-governed schools, which will be more independent financially; the plan has been that this independence would enhance the school's academic success (Schneider \& Barkol, 2007).

Before examining the way, school principals prioritize their roles, we must clarify and define the main skills school principals need to carry out their responsibilities: leadership, management, pedagogical, and emotional literacy skills. 
International Journal of Child, Youth and Family Studies (2020) 11(4.2): 37-56

\section{Leadership Abilities}

Popper (2007) dealt with two fundamental levels of influence, or types of leadership, that exist between leaders and followers: transactional leadership and transformational leadership. Transactional leadership is based on the understanding of mutual benefits. According to Bass (1985), transactional leaders motivate their followers by rewarding them for performing required tasks, and the act of rewarding is of benefit to both sides. Transformational leadership originates from the ability to create a high level of commitment between leader and followers.

In the Complete Range of Leadership, a model developed by Bass and Avolio (1993), the connection between leadership and efficiency is examined; they concluded that combining the two levels of influence brings about more effective leadership. As leadership is fundamental to principalship, we must explore the kind of leadership required in the field of education, where we regard the leadership of the principal as a unique kind of interaction between the principal and the school. According to Middleton (2001), "the role of leadership is to maintain the school community's energy and nurture the core purpose of increasing ability of all children and preparing students for the future" (p. 130).

Nathan (2002) and Frank (2013) viewed leaders as innovators and developers, people who challenge the status quo. According to them, leaders are initiators who take a long-term view focusing on the horizon; they are people-oriented and inspire trust, and they tend to ask "What?" and "Why?", make their own decisions, and do the right thing. Leadership is recognized as a required quality in principalship (Frank, 2013).

\section{Management Abilities}

Parames (1975) defined management as "a crossroad for heterogeneous knowledge, science and technology, of a pragmatic nature, available for those who have to make decisions and solve problems" (pp. 11-12). In the financial sector, management is measured by comparing input and output, which, according to Levacic (1997) should not be applied to education, where the connections between educational inputs, processes, products, and results cannot be meaningfully measured by such means. Rather, educational management measures values. Many in the field of education fear that the "good principals" of the past, who were mostly "good and humane teachers" (Kydd, 1997, pp. 116-117), would have no place in today's climate of systematic administrations (Oplatka, 2017).

Managers, according to Nathan (2002), tend toward conservatism, maintaining the status quo, focusing on the system, setting short-term goals, attending to the "bottom line", relying on control, and asking "How?" and "When?". School principals tend to see themselves as leaders rather than managers (Armstrong, 2016), a view that affects the way they prioritize management elements in their mission. 
International Journal of Child, Youth and Family Studies (2020) 11(4.2): 37-56

\section{Pedagogical Abilities}

Van Manen (1991) defined pedagogy as "a kind of leading [in which] the pedagogue walks behind the one who is led" (p. 37), and saw pedagogical authority as an educational leader's ability to motivate individuals and a whole community to deal with challenges and to advance toward solving them. But is the same kind of pedagogy that is implemented by the classroom teacher suitable for the pedagogical needs of the whole school? Selznick (1957) assigned importance to pedagogy in school management. Speaking of "creative leadership", he wrote:

The inbuilding of purpose ... involves transforming men and groups from neutral, technical units into participants who have a peculiar stamp, sensitivity, and commitment. This is ultimately an educational process. It has been well said that the effective leader must know the meaning and master the techniques of the educator. (pp. 149-150)

What we put forth here is the question of whether principals are only experts in pedagogy or also pedagogical leaders (Berkovich \& Eyal, 2015). Sergiovanni (1996) argued that pedagogy, when implemented as a form of pedagogical authority (which is a kind of leadership), has its own unique characteristics. In a previous study, we found that school principals tended to separate the two elements - leadership and pedagogy — rather than combine them (Schneider \& YitzhakMonsonego, 2010).

\section{Emotional Literacy Abilities}

According to Gardner (1983), in order to manage or lead people, one requires, among other things, two types of intelligence: interpersonal and intrapersonal. Interpersonal intelligence is the ability to gauge other people and to identify their mood, temperament, emotions, motives, and intentions, and to relate to all of these. One can also call this ability "social intelligence" (Armstrong, 1994, p. 239); it contributes substantially to increasing output by fostering cooperation among members of a community or group. "Intrapersonal intelligence allows us to value our being - who we are, what feelings we have, and why we are this way" (Armstrong, 1994, pp. 239-240). The strengths of intrapersonal intelligence lead us to introspection and selfreflection that can guide us to develop high self-esteem and enable us to lead, solve problems, and meet challenges (Armstrong, 1994; Naicker et al., 2013; Optalka, 2018; Tai \& Omar, 2018).

The recognition of emotional literacy as a necessary element in school leadership (Schneider \& Burton, 2008) and in pedagogy is part of a dialogue continued today in Emotions in Teaching and Educational Leadership (Oplatka, 2018), which emphasized the unique benefits to educational leadership of employing that ability. The ability to work with, to lead, or to manage people, results from a combination of interpersonal and intrapersonal intelligences. West-Burnham (2001) pointed out the relationship between leadership and emotional literacy (interpersonal and intrapersonal intelligences). 
International Journal of Child, Youth and Family Studies (2020) 11(4.2): 37-56

If leadership is seen as moving people from compliance to commitment, from acceptance to active engagement and from task completion to professional involvement, then inter-personal intelligence is the vital medium. It is impossible to conceptualize any model of leadership that does not have inter-personal intelligence as a key component. (West-Burnham, 2001, p. 13)

Traditionally, principals who possessed the skills of leadership, pedagogy, and management, were considered equipped to lead their schools; today, emotional literacy may also be regarded as necessary. The degree of importance that principals assign to each of these skills is what characterizes their individual styles.

The aim of the research presented here is to examine the place emotional literacy now has in a profession that has traditionally embraced pedagogy as its foremost element (Schneider et al., 2013; Schneider \& Yitzhak-Monsonego, 2010). The position emotional literacy holds will be juxtaposed with the position that educational policymakers have accorded pedagogy as empowering principals in their work and a contributing factor for raising the level of achievement in schools.

\section{Method}

\section{Participants}

The study was conducted in in the Research and Evaluation Unit of a Teachers Education College in central Israel from September 2009 to July 2010. There were 63 participants: five school principals and one supervisor participated in an interview, four principals were interviewed and also answered the questionnaire, and the other 53 principals only answered the questionnaire. The participants included both active and retired principals. The 16 men and 47 women ranged in age from 43 to 62 and varied in level of education, tenure, and type of school (see Table 1).

Participants were recruited through personal requests to answer the questionnaire, which was sent to school principals at the Central and Tel Aviv districts for answering. Participation in the study was voluntary. Quantitative processing of the questionnaire results was carried out, as well as content analysis of the questionnaire and the interviews.

As seen in Table 1, most of the participants were women. The dominant age bracket $(38.1 \%)$ was 51 to 60 years. Most (69.8\%) were principals of elementary schools, $79.4 \%$ had eight years tenure or more, and $76.2 \%$ were still active; $77.8 \%$ held a master's degree. 
International Journal of Child, Youth and Family Studies (2020) 11(4.2): 37-56

Table 1. Participants' Background Details

\begin{tabular}{lcc}
\hline Variable & $F$ & $\%$ \\
\hline Gender & & \\
$\quad$ Female & 47 & 74.6 \\
$\quad$ Male & 16 & 25.4 \\
Age & & \\
50 and under & 26 & 41.3 \\
51-60 & 24 & 38.1 \\
$\quad$ Over 60 & 13 & 20.6 \\
Tenure & & \\
$\quad 1-7$ years & 13 & 20.6 \\
$8-12$ years & 26 & 41.3 \\
$\quad \geq 13$ years & 24 & 38.1 \\
Employment status & & \\
$\quad$ Active & 48 & 76.2 \\
$\quad$ Retired & 15 & 23.8 \\
School & & \\
Elementary & 44 & 69.8 \\
Junior/High school & 19 & 30.2 \\
Education & & \\
BA & 6 & 9.5 \\
MA & 49 & 12.7 \\
PhD & 8 & \\
\hline
\end{tabular}

Note. $N=63$.

\section{Instruments}

Questionnaire: The research questionnaire had three parts: (1) demographic information, (2) an open question in which participants were asked to list three to five traits required for the appointment of a school principal, (3) participants were asked to rate (on a 1- to 10-point scale from least important to most important) four key traits (Schneider, 2004; Schneider \& Burton, 2005) associated with school principalship (leadership, management, pedagogy, and emotional literacy) by their importance to the task of managing a school, and to explain their answers. While processing the data, a few additional traits came up that were counted for the number of times they, or synonymous terms, were mentioned. These were grouped in the category "personal traits".

Interview: After the researchers had received all questionnaires, a group interview was conducted with 13 principals and one supervisor, aimed at validating the questionnaire results. Triangulation was then carried out between the questionnaire results and the results of the group interview. The group included nine active and four retired principals; four of the active principals had also answered the questionnaire. Combining the questionnaire and the interviews allowed us to identify, using statistical data, the participants concept of school principalship, with the interviews pinpointing the details of their positions and emotions. The technique of combining questionnaires and interviews transcends mere data integration, as it allows in-depth findings over a broad area as well as validation of the obtained findings. 
International Journal of Child, Youth and Family Studies (2020) 11(4.2): 37-56

\section{Findings}

Participants were asked to list three to five traits required for a school principal to be appointed. The responses included varied phrasings of the four key traits, or trait categories, that make up the role of principal: leadership, management, pedagogy, and emotional leadership. A few additional traits were also mentioned, which were counted as personal traits (see Table 2). Content analysis was conducted, in addition to counting the number of times each trait was mentioned.

Table 2. The Number of Times a Trait Associated with a Key Trait Was Mentioned

\begin{tabular}{lcc}
\hline Key trait & Count & $\%$ \\
\hline Leadership & 44 & 31 \\
Emotional literacy & 37 & 26 \\
Personal traits & 26 & 18 \\
Pedagogical abilities & 22 & 16 \\
Management skills & 12 & 9 \\
Total & 141 & 100 \\
\hline
\end{tabular}

Note. The number of answers is larger than the number of respondents (57) because respondents mentioned traits more than once, or not at all.

Table 2 shows that traits associated with leadership were those most frequently mentioned by respondents, followed by emotional literacy and personal traits, and finally, pedagogy and management skills. These findings agree with the four pillars model, developed by Schneider and Burton (2005). Respondents mentioned a wide range of qualities and characteristics that we associated with leadership. These included: charisma; the ability to manage teams using dialogue, power, personal responsibility, and personal example; being a visionary person; having good perception of systems and organizations, improvisation, leadership, and a high quality of service; self-confidence and the ability to show it; entrepreneurship, taking the initiative, and leading the team to achieving set goals along the way; being attentive and showing empathy to people; effectiveness; assertiveness; ability to delegate authority; capacity to guide and recruit staff, and to motivate, manage, and lead them toward various aims and purposes; and to foster professional growth for the teaching staff.

Regarding emotional literacy, which ranked second, participants listed the following traits: emotional regulation; good social skills; communicativeness; being capable of conducting reasonable, honest, and unbiased dialogues; having emotional strength and patience; seeing the positive side of things; being sensitive to others; possessing team-work capabilities, tenderness, and the capacity to understand social situations.

The qualities associated with pedagogy, the fourth key trait, included: knowledge of current pedagogy; pedagogical knowledge and experience; knowledge and understanding in the fields of pedagogy, education, and teaching; extensive education in the field of education; good articulation 
in speech and in writing; a pedagogical approach with faith in one's way, to the point of making personal sacrifices; getting into the field out of an ambition to do pedagogical work and not out of interest to only promote oneself; and a clear educational vision and ideology. A principal should be the head of the teaching staff; should encourage them to grow and become more professional; and should take on pedagogical responsibility and provide the correct, personally tailored, conditions, knowledge, and environment to allow each pupil to reach their highest capabilities. The principal should have the ability to combine theory with fieldwork, should be a professional in the field of teaching, learning, and evaluating, and should have sound pedagogical knowledge and the ability to combine pedagogical work and management while maintaining emotional quality control.

Management was ranked fifth (last) in importance among the key traits required by school principals. The managerial capabilities listed were: systemic thinking; organizational capacity; ability to clearly define a desired end product; ability to provide an integrated system vision; familiarity with organizational tools; mastery of administrative tools; familiarity with and understanding of the educational system; familiarity with, understanding of, and ability to implement the laws governing education; and the capacity to define, maintain, and implement budgeting processes. Additional traits mentioned were organizational skills; a good approach to systems and organizations; integrative and inclusive perception; good perception of systems and foresight regarding them; an education in management; the capacity to work by goal orientation; organizational attitude and an ability to organize and gather resources, utilizing time and human resources efficiently; good organizational understanding; administrative education; mission orientation; planning, and setting goals and measures; and the ability to work in an environment of regulations (and if regulations are lacking, the ability to provide them) coupled with mental flexibility.

Beyond these four elements — Campbell's (1999) three pillars with the addition of emotional literacy - participants rated personal traits as third in importance. Such traits include determination, self-awareness, consistency, wisdom and a wide intellectual scope, withstanding pressure and stressful conditions, loyalty, influential assertiveness, self-efficacy, personal responsibility, and setting a good example.

Following this open question, the participants were asked to rate (on a scale of 1 to 10) the importance of each of the following factors as they relate to school principalship: leadership, management, pedagogy, and emotional literacy, and to explain their choice of rating.

As seen in Table 3, participants rated leadership as most important, followed by emotional literacy, pedagogy, and management. These findings were then examined to determine whether the differences in rating were related to participants' background variables. By gender, women rated emotional literacy higher than did men; with the other elements, no clear differences were found. Age did not seem to have an effect, but tenure did, as seen in Table 4. 
International Journal of Child, Youth and Family Studies (2020) 11(4.2): 37-56

Table 3. The Importance of the Key Traits in School Principalship

\begin{tabular}{lcc}
\hline Key trait & $M$ & $S D$ \\
\hline Leadership & 9.60 & 0.83 \\
Emotional literacy & 9.16 & 0.89 \\
Pedagogy & 8.60 & 1.44 \\
Management & 8.16 & 1.42 \\
\hline
\end{tabular}

Note. The questionnaire was answered by 57 participants.

As seen in Table 4, attributing importance to pedagogy and emotional literacy is strongly related to tenure. In a Scheffe test conducted to discover the source of these differences we found that in pedagogy the difference was between those with 13 or more years of tenure and those with 8 to 12 years of tenure, the former rating pedagogy lower than the latter, who gave it the highest rating.

In the emotional literacy factor, the test did not find the source of the differences, but looking at the different group averages shows a similar trend to that revealed for pedagogy, with those of 13 years of tenure or more giving it the lowest rating while those with 8 to 12 years of tenure ranked it highest.

Table 4. Tenure and the Importance of Leadership, Management, Pedagogy, and Emotional Literacy in Principalship: Analysis of Variance

\begin{tabular}{lcccc}
\hline Key trait & Tenure & $M$ & $S D$ & $F$ \\
\hline Leadership & $1-7$ & 9.77 & 0.43 & .68 \\
& $8-12$ & 9.61 & 1.19 & \\
Management & $\geq 13$ & 9.50 & 0.68 & \\
& $1-7$ & 8.38 & 0.76 & .09 \\
Pedagogy & $8-12$ & 8.56 & 1.68 & \\
& $\geq 13$ & 7.65 & 1.22 & \\
& $1-7$ & 9.00 & 1.47 & .01 \\
Emotional literacy & $8-12$ & 9.06 & 0.80 & \\
& $\geq 13$ & 7.85 & 1.72 & \\
& $8-7$ & 9.23 & 1.09 & .05 \\
& $\geq 13$ & 9.44 & 0.61 & \\
\hline
\end{tabular}

Note. The answers of the 53 participants (of 57) who reported their years of tenure are included in this analysis. 
International Journal of Child, Youth and Family Studies (2020) 11(4.2): 37-56

\section{Discussion}

In this study we set out to examine principals' perceptions regarding the importance of each of the four pillars of principalship: leadership, management, pedagogy, and emotional literacy. The findings revealed that principals' ratings contradicted the views of educational policymakers who rated pedagogy as the most important of the pillars: principals rated leadership as most important. We shall turn to examining the principals' ratings of the four pillars and present some of the reasons they offered to account for them.

\section{Leadership as the Foremost Quality}

Middleton (2001) viewed leadership as the main quality required for school principalship. Principals' leadership role, both in the community and in the school, is to preserve community spirit and sustainability and nurture a focused common goal that will bring about better skills and training for the school's pupils.

Indeed, leadership was ranked high by most of the participants, as is consistent with the results of a previous study (Schneider, 2004). Recognizing leadership as the foremost quality (Fiarman, 2015) is consistent with McDonald's (1998) observation that:

School leadership is very much more than the passive acceptance of staff that they must do as the head teacher says simply because the individual concerned has been appointed to that position. A school leader, at any level of the organisation, has won the trust, belief and confidence of staff to a significant degree and these are assets which the staff has given to the leader. (p. 171)

The rating of leadership as most important also confirms Lambert's (1998) description of school leadership as incorporating a number of core concerns: creating, among other things, actions that mean collaborative learning; cooperating; joint structuring of meaning and knowledge; fostering opportunities for creative work and development; mediating knowledge and ideas, perceptions and values, beliefs, information, and assumptions using continuous dialogue; questing collaboratively for means to develop novel ideas; managing through a reflective process; and, above all, implementing activities in a climate of shared values and current information.

\section{Pedagogy as an Ambivalent Factor}

The participants rated pedagogy third in the list of traits required for appointment as a school principal. This is consistent with previous findings (Schneider, 2004) where both teachers and retired military personnel in career retraining for managerial posts in education rated pedagogy as third in the list of desired traits.

Pedagogical skills and capabilities listed by the participants included: teaching abilities, the ability to implement pedagogical tools, professionalism, the ability to instruct and provide

professional guidance in all matters related to pedagogical issues, and familiarity with school 
International Journal of Child, Youth and Family Studies (2020) 11(4.2): 37-56

systems and study programs - knowing and understanding the complexities of a school curriculum and being able to implement it.

\section{Is Pedagogy a Necessary Element?}

If the main purpose of the school is to strive for academic achievement, principals should, first and foremost, consider themselves as pedagogues. However, as seen in the present study, both in the questionnaire and the interviews, some principals explained that pedagogy can be picked up on the job, or that, as with management, it is something others can do:

Management and pedagogy are subjects that can be trusted to others, though not abandoned to their hands.

Undoubtedly, a principal should be knowledgeable in pedagogy, though if they are lacking in this field, they may appoint someone else who can make up for what they lack.

Pedagogy and management are very important, but these are areas that people in other positions can deal with, rather than the principal.

If the principal is smart enough to surround himself with a professional staff, the staff can do the task well.

Pedagogy — desirable, but a staff member could also be an expert in it.

The vice-principal can take care of the mission, this means that the element of pedagogy is not required for the appointment of a school principal since someone else can.

Pedagogy can be learnt. I could be appointed principal without first being a pedagogue and catch up on missing knowledge in this area as I perform my duties as principal.

Others, a minority of the participants, stated that the question is a matter of terminology, a linguistic difference regarding the essence of pedagogy: they felt that principals could not simply put pedagogy aside:

It is important for the principal to broadcast and express in his conduct an agendabased leadership alongside professionalism in his field — the pedagogy he leads, guides, and assimilates.

... one should have a pedagogical approach and a selected direction in which to lead.

It is easy to escape towards management and much more difficult to do pedagogical work. Tasks in "management" are measurable, ad hoc, and solvable. Tasks in 
pedagogy are prolonged and require a change in perception, in goal statements, and in ways of action - not a simple matter... In today's post-modern age it is mandatory for every principal to be a first-class pedagogue, before anything else.

Regarding the question of whether selection of school principals should be based primarily on pedagogical skills, the following answers were offered:

I think the area of pedagogy sets us apart, compared to other professions, and therefore I feel it is one of the central themes one should master as they enter into school principalship.

A principal who is only a pedagogical leader will not succeed in principalship.

It is a complicated question that [will] make principals wonder.

I think the pedagogical side is highly important and there cannot be a situation where a principal has no knowledge in this area, but if we look at the reality around us, so many individuals from other backgrounds with no knowledge of pedagogy enter the education system as principals, as educational leaders, and they do quite well.

If in the past, a pedagogue was the principal, today that is not the case. There are many other factors which determine success; pedagogy may be important but not the most important.

A minority of the participants saw pedagogy as a central element:

Even if a principal is not fully familiar with the curriculum in every detail, she or he should be a pedagogical leader in that they should know how to empower the forces that may lead the teaching staff in various fields and areas of knowledge.

As a pedagogical leader, the principal does not necessarily have to be familiar with all details of school curricula, but should be able to guide the education team while carrying out all other responsibilities.

When evaluating teachers, a pedagogue principal should have a pedagogical toolbox, without which their principalship is lacking. The toolbox should include knowledge in evaluating classes and evaluating the interaction between the teacher and the pupils. That is why I think pedagogical knowledge is one of the required skills for a principal.

I ask myself in what way is a school principal different from others in management positions in industry or elsewhere? Pedagogy makes the difference that sets school principals apart from other managers. 
International Journal of Child, Youth and Family Studies (2020) 11(4.2): 37-56

The supervisor who was interviewed saw pedagogical leadership as required for the leadership of school principals, and concluded:

Today's school principals are required to have more substantial pedagogical leadership than before. Five or ten years ago, it was about organizational skills and having good internal and external relations, which were based on emotional literacy. Today that isn't enough. Today, in addition to all those management skills which are required for all managers in other industries, a school principal is also required to show pedagogical leadership. It would be desirable for him to know the "curricular outline" of the areas of knowledge, but that is not to say he should know all curricula in all detail. A pedagogical principal can lead a professional dialogue with the staff in order to upgrade teaching processes in the classroom.... A principal is required to evaluate the pedagogical work of a teacher based on observing their class work. Without pedagogical knowledge that would not be possible. In addition, one must take into account that school principals are required to teach in class as a part of their job. During those hours they must act as role models and set a personal example of optimal teaching processes, learning, and evaluation. In these classes the principal's pedagogical leadership is tested by the pupils and teachers. A principal who enters the classroom and delivers a lesson by the power of his authority alone, and not by virtue of his authoritative pedagogical knowledge, cannot serve as a model for others. How could a principal who does not know how to manage a class provide feedback for a teacher after observing their class and manage a pedagogical dialogue in a way that mutual learning will take place? A pedagogical principal should guide the group through a session where there will be mutual inspiration based on his didactic pedagogical knowledge. As a pedagogical leader, the principal must know how to teach and how to manage a dialogue with the staff that will result in continuous upgrading of pedagogical-didactic processes. A dialogue based on knowledge turns the principal into a pedagogical leader of the learning and teaching community.

\section{Pedagogical Skills Required}

If, indeed, a principal must possess pedagogical skills, how do these compare with the pedagogical skills required of teachers? According to the participants:

These are obviously two different things, but if you succeeded as a teacher in the area of pedagogy then it is reasonable to assume that you might be able to build on that and develop principalship skills in the field of pedagogy. And again, I think it is one of those things one can attain - the entire field of pedagogy — and until then you should also be able to find those people who fit your needs and could do those things and you'll just supervise them. 
International Journal of Child, Youth and Family Studies (2020) 11(4.2): 37-56

I think that a pedagogical leader is a leader. If the principal is a pedagogue and also a leader then, in fact, you have all the aspects you are looking for.

I only wish to make one distinction. After all, we as principals of elementary schools were selected until today as teachers who grew to become principals. Naturally, pedagogical leadership is such because we grew as such.

In a world where managerial positions are a profession onto themselves, the question is whether the most senior pedagogical leader at the school would be not the principal, but another member of the educational team:

I have in mind a pedagogical leader ... the question is: could she lead the school? And if I understand the question correctly, what would be a sufficient condition ... for me to know pedagogy or for me to know how to be a leader? To support a teacher, to give her all she needs so she can be a pedagogical leader in her classroom, is my role as principal. How do I do that? I see her and ask her - How are you? What might you need today? Will it suit you to act as such and such, and to do so and so this year? What would you like to do right now? Etc. That's the emotional thing.

The principal should master pedagogical abilities. Yukl (1998) raised questions about the extent to which skills are transferrable from one type of organization to another, stating that there are difficulties concerning the transfer of lower-level managers due to differences in technical skills. As for high-level management, Katz (1955) proposed that high-level managers, possessing good human relations and conceptual skills, can be shifted easily from one industry to another without losing effectiveness.

Because of variations in ownership, tradition, organizational climate, and culture, Yukl (1998) thought that conceptual and technical elements can be transferred to another organization but particular knowledge elements will need to be relearned.

\section{The Principal as a Jazz Band Leader}

In an attempt to examine the issue of pedagogical management as a central element in the system, Barkol (2010), an education-management researcher, claimed that a multidirectional approach is required when dealing with school management issues because the role of the principal embodies all elements: leadership, management, pedagogy, and emotional literacy. The increasing demands of this all-in-one role make it more complex than is implied by the term "pedagogical leader" - suggested by the Ministry of Education to denote a principal — which omits recognition of management and leadership in the principal's role, not to mention emotional literacy. As the head of an educational organization, the principal should reflect its uniqueness. Educational organizations have a particular set of morals, beliefs, methods, and approaches, and a school 
International Journal of Child, Youth and Family Studies (2020) 11(4.2): 37-56

principal must preserve and develop the composite of qualities characterizing these institutions that is not found in other organizations.

Barkol (2010) stressed that along with the need to function as a member of an organization, an administrator, and a politician, the principal must first of all function as a leader for the teachers, thus becoming also a leader for the pupils. Leadership that energizes the teachers will carry a message that will determine the school climate and affect the pupils as well.

As for the essential pedagogical aspect of school principalship, this view of leadership is consistent with that of Schneider et al. (2013). Addressing this pedagogical essence, Barkol (2010) argued that the headmaster of the school, as a principal, promotes a learning community; without that learning community there is no ability to promote the organization. A learning community is one whose members all have their eyes open to the environment; that is, they know what is being done around them, study it, decode it, analyze it, and advance the organization accordingly. A school principal today is no longer a conductor of a planned and structured philharmonic orchestra, but a leader of a jazz band where everyone improvises on their own but everyone plays along with a central leader who allows every musician to express their skills and abilities.

\section{Conclusions and Recommendations}

The purpose of this study was threefold: (1) to determine the essence of the toolkit that is required for performing the role of principal, (2) to examine the changing role of pedagogy and the increasing recognition of emotional literacy as elements in principalship, and (3) to ascertain the importance that principals attribute to each component of classic school principalship leadership, management, pedagogy — and to the additional component of emotional literacy. Our research findings clearly define and rate the essential elements of principalship as perceived by principals: leadership and emotional literacy were both rated above pedagogy and management.

Our finding that principals gave pedagogy a low ranking deserves special attention. The Israeli Ministry of Education regards pedagogical leadership as the ideal type of leadership for principals. However, our findings reveal that principals do not share that view: they regard pedagogical leadership as much more necessary for teachers than for principals. In a study among aspiring principals, teachers taking a principalship course presented pedagogy as an existing strength (Schneider, 2004), and felt that working in classrooms and in schools had given them sufficient exposure to pedagogy and that therefore they did not need extra pedagogical training to become principals. This raises a question that should be looked into. Does the same type of pedagogy implemented by teachers in a classroom meet the pedagogical requirements for an entire school? Is the pedagogy of teachers the same as the andragogy (adult pedagogy) required by the principal's role?

The principals' low ranking of pedagogy contradicts the ongoing attempt by the Israeli Ministry of Education to establish pedagogical leadership as the central element in principalship 
and to enhance the importance of pedagogy over other elements in the role of school principal (Mendel-Levi \& Bozo-Schwartz, 2016). As such, the findings indicate the need for the Ministry of Education, when formulating policy, to take into account recent changes in the role of the principal. The question arises: What areas should we now be emphasizing when training and developing school principals?

Meeting the challenge of creating new updated educational institutions will require the establishment of an infrastructure for training principals that can nurture and develop their capabilities in the area of emotional literacy, as well as in the classic skills of leadership, pedagogy, and management. The ability of principals, both active and aspiring, to identify these needs and requirements, as shown in Schneider (2004), is a valuable resource. They should be consulted and participate as equal partners in designing the program, and continue to dialogue with the design team during the training program for aspiring principals and later during training and development on the job.

Principal training is part of a lifelong learning process. It begins with the decision to become a principal, and continues throughout the performance of the role. Each principal develops his or her own unique way of performing the role. However, the development of a common knowledge base is the responsibility of training authorities. It should include all four elements of principalship: leadership, management, pedagogy, and emotional literacy. At the end of the training, each principal chooses his or her own path and personal way of performing the role.

An essential element of principal training is diagnosis of the strengths and weaknesses of the candidates, a process performed by the instructors and the candidates together. The candidates rely on their intrapersonal intelligence — an aspect of emotional literacy (Armstrong, 1994) — to engage in introspection and self-reflection throughout this process.

To the extent that this diagnosis is made accurately, training programs can be successful and address personal needs. Identification of the areas of empowerment required for each component of the training program should be carried out with the involvement and partnership of the candidates. Candidates should be involved in guiding their learning, involved in the decisionmaking process related to the learning course, and feel that there is a focus on issues relevant to them that allow them to use their rich experience and engage in mutual learning with colleagues (Merriam \& Caffarella, 1999).

Based on an assessment of the foundations required for preparation and training for principalship in the areas of leadership, management, pedagogy, and emotional literacy, and on an assessment of the qualities of each candidate, it is possible to determine the elements required to prepare and train the candidates to assume the management of an educational institution. These principles should guide us in building and constructing the training process (Schneider \& Burton, 2005). 
It is not recommended to set a uniform model for principal training and development, or to try and form principals in too rigid a format. Only versatility and a wide range of abilities can advance and energize the educational system. There is great danger in establishing a uniform model of the educational leader.

Principals of educational institutions with leadership and management abilities, appropriate pedagogical vision, and emotional literacy are leaders of students, faculty. and community, and thus should have unique educational characteristics that will allow them, as in the classical Greek view of pedagogy, to accompany the youth and bring them to adulthood as whole adults. 
International Journal of Child, Youth and Family Studies (2020) 11(4.2): 37-56

\section{References}

Armstrong, M. (2016). Armstrong's handbook of management and leadership for HR: Developing effective people skills for better leadership and management. Kogan Page.

Armstrong, T. (1994). Multiple intelligences in the classroom. Association for Supervision and Curriculum Development.

Barkol, R. (2010). From military career to principalship: A career transition as inter-cultural transition. In E. Hertzog \& S. Waldan (Eds.), At teachers' expense: Gender and power in Israeli education (pp.157-179). Carmel (Hebrew).

Bass, B. M. (1985). Leadership and performance beyond expectations. Free Press.

Bass, B. M., \& Avolio, B. J. (1993). Transformational leadership: A response to critiques. In M. M. Chemers \& R. Ayman (Eds.), Leadership theory and research: Perspectives and directions (pp. 49-80). Academic Press.

Berkovich, I., \& Eyal, O. (2015). Educational leaders and emotions: An international review of empirical evidence 1992-2012. Review of Educational Research, 85(1), 129-167. $\underline{\text { doi: } 10.3102 / 0034654314550046}$

Bisschoff, T. (2014). Exploring the school leadership landscape, changing demands, changing realities [Book review]. British Journal of Educational Studies, 62(3),370-372. $\underline{\text { doi:10.1080/00071005.2014.944399 }}$

Campbell, C. (1999). Exploring recent developments and debates in education management. Education Policy, 14(6), 639-658. doi:10.1080/026809399286143

Davies, B. (1997). Rethinking the educational context: A re-engineering approach. In B. Davies \& L. Ellison (Eds.), School leadership for the 21st century: A competency and knowledge approach (pp. 11-22). Routledge.

Fiarman S. E. (2015). Developing teacher leadership. In S. E. Fiarman, Becoming a school principal: Learning to lead, leading to learn (pp. 71-94).Harvard Education Press.

Frank, A. (2013). Leadership motivating to practice and involvement: Nine steps on the way from management to leadership. MOFET Bulletin, 51, 82-88 (Hebrew).

Gardner, H. (1983). Frames of mind: The theory of multiple intelligences. Basic Books.

Handy, C. (1995). The age of unreason. Arrow Business.

Katz, R. L. (1955) Skills of an effective administrator. Harvard Business Review, 33(1), 3-42. 
International Journal of Child, Youth and Family Studies (2020) 11(4.2): 37-56

Kydd, L. (1997). Teacher professionalism and managerialism. In L. Kydd, M. Crawford, \& C. Riches (Eds.), Professional development for educational management. Open University.

Lambert, L. (1998). How to build leadership capacity. Educational Leadership, 55(7), 17-19.

Levacic, R. (1997). Managing resources in educational institutions: An open systems approach. In M. Preedy, R. Glatter, \& R. Levacic (Eds.), Educational management: Strategy, quality and resources (pp. 127-136). Open University.

MacBeath, J., Moos, L., \& Riley, K. (1998). Time for a change. In J. MacBeath (Ed.), Effective school leadership: Responding to change (pp.20-30). Paul Chapman. doi:10.4135/9781446252086.n2

MacDonald, A. (1998). Postscript. In J. MacBeath (Ed.), Effective school leadership: Responding to change (Ch. 11). Paul Chapman. doi:10.4135/9781446252086.n11

Mendel-Levi, N., \& Bozo-Shwartz, M. (2016). The making of a school: Practical knowledge on pedagogical leadership. Avnei Rosha Institute (Hebrew).

Merriam, S. B., \& Caffarella, R. S. (1999). Learning in adulthood (2nd ed.). Jossey Bass.

Middleton, R. (2001). Leadership in the real world: A postscript. In T. J. Sergiovanni (Ed.), Leadership: What's in it for schools? (Ch. 7). Routledge Falmer.

Naicker, I., Chikoko, V., \& Mthiyane, S. E. (2013). Instructional leadership practices in challenging school contexts. Education as Change, 17, S137-S150. doi:10.1080/16823206.2014.865999

Nathan, M. (2002). A handbook for head teachers. Kogan Page/Open University.

Oplatka, I. (2017). Principal workload: Components, determinants and coping strategies in an era of standardization and accountability. Journal of Educational Administration, 55(5), 552-568. doi:10.1108/JEA-06-2016-0071

Oplatka, I. (Ed.). (2018). Emotions in teaching and educational leadership. MOFET Institute.

Parames, C. (1975). The nature and content of management. In V. Houghton, R. McHugh, \& C. Morgan (Eds.), Management in education. Reader 1: The management of organisations and individuals. Ward Lock Educational \& the Open University.

Popper, M., (2007). Transformational leadership: A psychological approach (Ch. 1). Tel Aviv University. 
International Journal of Child, Youth and Family Studies (2020) 11(4.2): 37-56

Schneider, A. (2004). Transforming retired military officers into school principals in Israel [Unpublished doctoral dissertation]. University of Leicester. https://leicester.figshare.com/articles/Transforming_retired_military_officers_into_school_pri ncipals_in_Israel/10078349/1

Schneider, A., Altarac, H., \& Yitzhak-Monsonego, E. (2013). Leadership lane, structure, role and training: The nature of the leading school team as perceived by school principals and staff. Research and Evaluation Unit, Beit Berl Academic College.(Hebrew)

Schneider, A., \& Barkol, R. (2007). The Officers to Education project: A retrospective. International Journal of Educational Reform, 16(2), 169-185. doi:10.1177/105678790701600205

Schneider, A., \& Burton, N. (2005). An ideal type? The characteristics of effective school principals as perceived by aspiring principals both from within education and those from an alternate career path. Management in Education, 19(2), 6-9. doi:10.1177/08920206050190020201

Schneider, A., \& Burton, N. (2008). Personal intelligences: The fourth pillar of school principalship? Management in Education, 22(3), 34-42. doi:10.1177/0892020608093263

Schneider, A., \& Yitzhak-Monsonego, E. (2010). Emotional literacy: A critical element in school principalship. Research and Evaluation Unit, Beit Berl Academic College (Hebrew).

Selznick, P. (1957). Leadership in administration. University of California Press.

Sergiovanni, J. T. (1996). Leadership for the schoolhouse. Jossey-Bass.

Tai, M. K., \& Omar, A. K. (2018). The relationship between emotional intelligence of school principals in managing change and teacher attitudes towards change. International Journal of Leadership in Education Theory and Practice, 22(4), 469-485.

doi:10.1080/13603124.2018.1481535

Van Manen, M. (1991). The tact of teaching: The meaning of pedagogical thoughtfulness. State University of New York Press.

West-Burnham, J. (2001). Interpersonal leadership. NCSL Leading Edge Seminar, Nottingham, National College for School Leadership. 